\title{
EPIKARDINIO RIEBALINIO AUDINIO TŪRIO BEI STORIO SKIRTUMAI TARP PATYRUSIŲ MIOKARDO INFARKTĄ IR ŠIRDIES BEI KRAUJAGYSLIŲ LIGOMIS NESISKUNDŽIANČIŲ ASMENŲ
}

\author{
Donatas Austys ${ }^{1}$, Eglė Bulotaitėe ${ }^{2}$, Nomeda Rima Valevičiene் ${ }^{2,3}$, Rimantas Stukas ${ }^{1}$ \\ ${ }^{1}$ Vilniaus universiteto Medicinos fakulteto Visuomenes sveikatos institutas, \\ ${ }^{2}$ Vilniaus universiteto Medicinos fakulteto Radiologijos, branduolinès medicinos ir \\ medicinos fizikos katedra, ${ }^{3}$ Vilniaus universiteto ligoninès Santariškiu kliniku \\ Radiologijos ir branduolinès medicinos centras
}

Raktažodžiai: epikardinis riebalinis audinys, visceralinis riebalinis audinys, miokardo infarktas.

\section{Santrauka}

Moksliniais tyrimais nustatyta, kad didelis visceralinio riebalinio audinio, kuriam priskiriamas ir epikardinis riebalinis audinys (ERA), susikaupimas didina daugelio širdies ir kraujagyslių ligų riziką. Kaip bebūtų, pateikiami prieštaringi tyrimų rezultatai: vieni tyrejai nustate, kad didesnis ERA susikaupimas didina koronarinès širdies ligos riziką, tačiau kitiems tyrejams to patvirtinti nepavyko. Lietuvos gyventojų populiacijai būdingas ERA susikaupimas nebuvo tirtas.

Tyrimo tikslas - palyginti ERA storio maksimumus bei tūrius tarp patyrusių miokardo infarktą ir širdies bei kraujagyslių ligomis nesiskundžiančių Lietuvos gyventojų grupių.

Tyrimo medžiaga ir metodai. I tyrimą buvo įtraukiami 25 - 85 metu amžiaus galimai širdies ir kraujagyslių ligomis sergantys pacientai, kuriems buvo atliekama širdies ir kraujagysliu magnetinio rezonanso tomografija. Panaudojant MRT vaizdus buvo išmatuoti ir apskaičiuoti ERA storio maksimumai bei tūriai. Anketinès apklausos būdu buvo registruojamas tiriamujų ūgis, svoris, amžius, lytis ir lètinès neinfekcinès ligos, kuriomis pacientai sirgo prieš tyrimą ir jo metu.

Rezultatai. Tyrime dalyvavo 215 pacientų: 160 patyrusių miokardo infarktą bei 55 širdies ir kraujagyslių ligomis nesiskundžiančių asmenų. Vyrai sudare $67 \%$ tiriamųų, moterys - 33\%. Pacientų vidutinis amžius buvo $56,0 \pm 12,6$ metai, vidutinis kūno masès indeksas $-28,15 \pm 5,72 \mathrm{~kg} / \mathrm{m}^{2}$. Visų tiriamųų vidutinis ERA storio maksimumas buvo $8,33 \pm 2,95$ $\mathrm{mm}$, vidutinis tūris $-141,74 \pm 47,35 \mathrm{~cm}^{3}$. Širdies ir kraujagyslių ligomis nesiskundžiančių ir miokardo infarktą patyrusių pacientų vidutiniai ERA storio maksimumai atitinkamai buvo $6,27 \pm 1,33 \mathrm{~mm}$ ir $9,04 \pm 3,02 \mathrm{~mm}\left(\mathrm{p}=1,5^{*} 10^{-12}\right)$, o tūriai $-101,06 \pm 26,41$ $\mathrm{cm}^{3}$ ir $155,73 \pm 44,85 \mathrm{~cm}^{3}\left(\mathrm{p}<2,2 * 10^{-16}\right)$. Išmatuoti ERA tūriai ir storio maksimumai buvo sunormalizuoti - tiek faktinių, tiek ir sunormalizuotų matavimų rezultatai skyrèsi statistiškai reikšmingai.

Išvados. Patyrusių miokardo infarktą pacientų epikardinio riebalinio audinio tūriai ir storio maksimumai buvo didesni nei širdies ir kraujagyslių ligomis nesiskundžiančių asmenų.

\section{Ivadas}

Širdies ir kraujagyslių ligos yra pagrindinè mirties bei viena iš pagrindinių vyresnio amžiaus žmonių negalios priežasčių pasaulyje. Kiekvienais metais daugiau nei 17,3 mln. žmonių miršta dèl širdies ir kraujagyslių ligų. Miokardo infarktas kasmet lemia 7,3 mln. mirčių [1]. Pripažindama šią problemą Pasaulinė Širdies Federacija (angl. World Heart Federation) iškèle siekị iki 2025 metų sumažinti mirtingumą dèl širdies ir kraujagyslių ligų bent 25 procentais [2].

Sergant širdies ir kraujagyslių ligomis dèl vykstančių patofiziologinių procesų gali būti pažeidžiamos širdies, smegenų, periferinès ir kt. kraujagyslès. Aterosklerozinio proceso sukeltas vainikinių arterijų pažeidimas yra vadinamas išemine arba koronarine širdies liga (KŠL). Naujausiais paskelbtais Amerikos Širdies Asociacijos (angl. American Heart Association) duomenimis, Jungtinèse Amerikos Valstijose KŠL serga 15,5 mln. vyresniu nei 19 metų amžiaus suaugusių žmonių, iš jų 7,6 mln. patyrè miokardo 
infarktą (MI) [3]. Pagal sergamumo bei mirtingumo nuo širdies ir kraujagyslių ligų rodiklius Lietuva priklauso didelès rizikos zonai [4]. 2013 metų duomenimis, Lietuvoje ligotumas kraujotakos sistemos ligomis siekia 23943 atvejus 100 tūkst. Lietuvos gyventojų, ligotumas MI siekia 272 gyventojus iš 100 tūkst. [5].

Išeminė širdies liga gali pasireikšti krūtinès angina, širdies nepakankamumu, koronarine mirtimi ir MI. KŠL rizikos veiksniai skirstomi i dvi grupes: nepakeičiamus (amžius, vyriška lytis, paveldimumas) ir modifikuojamus, kuriuos galima valdyti. Antrajai grupei priklauso padidèjęs kraujospūdis (hipertenzija), rūkymas, padidèjęs lipidų kiekis kraujyje, cukrinis diabetas, padideję̨s kraujo krešumas bei klampumas, nutukimas, mažas fizinis aktyvumas, stresas ir depresija [4]. Remiantis pastarujų metų tyrimų rezultatais, didesnis epikardinio riebalinio audinio (ERA) susikaupimas taip pat daro įtaką aterosklerozès bei KŠL vystymuisi. Kaip bebūtų, pateikiami prieštaringi tyrimų rezultatai: vieni tyrëjai nustate, kad didesnis ERA susikaupimas didina šių ligų riziką, tačiau kitiems tyrèjams to patvirtinti nepavyko [6-13].

ERA yra visceralinio riebalinio audinio sudedamoji dalis, turinti bendrą embriologinę kilmę ir produkuojanti tokius pat citokinus, vadinamus adipokinais [14-16]. Epikardinis riebalynas, supantis širdị ir jos vainikines kraujagysles, yra išsidėstęs tarp išorinès miokardo sienos ir visceralinio perikardo sluoksnių [14]. Jis paprastai sudaro apie 20 procentų viso jos svorio $[15,17]$. Fiziologiškai ERA gamina prouždegimines (TNF- $\alpha, \mathrm{MCP}-1$, IL-1 $\beta$, IL-6 ir kt.) ir antiaterosklerozines medžiagas (pvz., adiponektiną), tarp kurių normaliomis sąlygomis išlieka pusiausvyra [14,18]. Didelis riebalinio audinio susikaupimas apie širdị lemia šio audinio hipoksiškumą ir disfunkciją [19], pasireiškiančią didesniu kiekiu sekretuojamų uždegimą skatinančių citokinų, turinčių ịtakos aterominès plokštelès susidarymui ir KŠL progresavimui $[14,16]$.

Epikardinis riebalynas dažniausiai vertinamas echoskopijos, kompiuterinès tomografijos ar magnetinio rezonanso tomografijos būdu. 2013 metais publikuotas kompiuterinès tomografijos būdu Vokietijoje atliktas didelès tiriamuju imties $(\mathrm{n}=4093)$,The Heinz Nixdorf Recall“ tyrimas parode, jog miokardo infarktą patyrusių asmenų epikardinio riebalyno tūris buvo didesnis nei kontrolinès grupès (tūriai atitinkamai lygūs $121 \mathrm{ml}$ ir $95 \mathrm{ml}, \mathrm{p}<0,001$ ), nepriklausomai nuo kitų širdies ir kraujagyslių ligų rizikos veiksnių [7]. Transtorakalinès echokardioskopijos būdu atliktų tyrimų duomenimis, didesnis ERA storis yra statistiškai reikšmingai susijęs su sunkesniu koronarinès širdies ligos laipsniu [11,20-22]. Panašių tyrimų, kurie būtų atlikti Lietuvoje, nepavyko rasti.
Sio tyrimo tikslas - palyginti epikardinio riebalinio audinio storio maksimumus bei tūrius tarp patyrusių miokardo infarktą ir širdies bei kraujagyslių ligomis nesiskundžiančių Lietuvos gyventojų grupių.

\section{Darbo medžiaga ir metodika}

Tyrimas atliktas vadovaujantis papildytu $2013 \mathrm{~m}$. vasario $12 \mathrm{~d}$. Vilniaus regioninio biomedicininių tyrimų etikos komiteto išduotu leidimu Nr. 158200-13-576-178 (leidimas papildytas $2014 \mathrm{~m}$. balandžio $8 \mathrm{~d}$., papildymo Nr. 158200576-PP1-14). Tyrimo duomenys rinkti Vilniaus universiteto ligoninès Santariškių klinikų (VUL SK) Radiologijos ir branduolinès medicinos centre nuo 2014 metų balandžio ménesio iki 2015 metų vasario mènesio (imtinai). I tyrimą buvo ịtraukiami 25 - 85 metų amžiaus galimai širdies ir kraujagyslių ligomis sergantys pacientai, kuriems šiame centre buvo atliekama širdies ir kraujagyslių magnetinio rezonanso tomografija.

Magnetinio rezonanso tomografijos procedūra. Magnetinio rezonanso tomografija buvo atliekama Siemens MAGNETOM Avanto 1,5T aparatu (Siemens AG, Erlangen, Vokietija). Magnetinio rezonanso tomografijos vaizdai buvo vertinami pasinaudojant „MedDream WEB DICOM Peržiūra" - DICOM vaizdų peržiūros per interneto naršyklę moduliu (UAB „Softneta“, Kaunas, Lietuva). Epikardinių riebalų tūris buvo apskaičiuojamas pagal modifikuotą Simpsono metodiką [16]. Pasinaudojant naudotos programinès įrangos ploto matavimo ịrankiu rankiniu būdu trumpųjų ašių kairiojo skilvelio diastolès pabaigos magnetinio rezonanso tomografijos vaizduose buvo apibréžiami kairijji ir dešinijji skilvelị dengiančio epikardinio riebalinio audinio kontūrai (tarp perikardo ir miokardo). Taip apskaičiuotus skirtinguose pjūviuose matomo riebalinio audinio plotus padauginus iš pjūvių storio $(8 \mathrm{~mm})$ buvo apskaičiuojami tuose pjūviuose užfiksuoti epikardinio riebalinio audinio tūriai. Bendras epikardinio riebalinio audinio tūris buvo apskaičiuojamas sudedant skirtinguose pjūviuose išmatuotus skilvelius dengiančio riebalinio audinio tūrius. Be to, pasinaudojant 4 kameru vaizdais buvo išmatuoti skilvelių laisvąsias sienas dengiančio epikardinio riebalinio audinio storio maksimumai ir skilveliu pertvaros ilgis, matuojant atstumą nuo menamo pertvaros taško, esančio per vidurị, tarp triburio ir dviburio vožtuvų jungčių su pertvara, iki menamo skilvelių pertvaros taško, esančio tarp vidinių miokardo paviršių skilvelių viršūnèse.

Kiti kintamieji. Visi tyrime sutikę dalyvauti pacientai anketinès apklausos būdu buvo apklausiami apie ligas, kuriomis šiuo metu serga ar sirgo anksčiau. Anketinès apklausos būdu taip pat buvo registruojamas tiriamujų ūgis, svoris, amžius ir lytis. Pasinaudojant ūgio ir svorio duo- 
menimis, buvo apskaičiuojamas kiekvieno paciento kūno masès indeksas bei kūno paviršiaus plotas (KPP). Kūno paviršiaus plotas buvo apskaičiuotas pasinaudojant dviem žinomomis metodikomis: Du Bois ir kt. aprašyta metodika, kai KPP $=0,007184 *$ svoris $^{0,425 *}$ ūgis $^{0,725}[23]$, bei Mosteller ir kt. aprašyta metodika, kai $\mathrm{KPP}=(\text { svoris*ūgis } / 3600)^{0,5}$ [24,25]. Pasinaudojant apskaičiuotais kūno paviršiaus plotais bei išmatuotais širdies pertvaros ilgiais buvo apskaičiuotos normalizuotos epikardinio riebalinio audinio tūrių bei storių reikšmès (padalinant faktinius tūrius bei storius iš faktinių KPP ar skilvelių pertvaros ilgių reikšmių bei padauginant iš didžiausios KPP ar skilvelių pertvaros ilgio faktinès reikšmès imtyje).

Statistinė rezultatų analizè. Rezultatų statistinè analizè atlikta pasinaudojant R paketu (versija 3.1.2). ShapiroWilk testu buvo patikrintas skirstinių normalumas. Pagal normalụji dèsni pasiskirsčiusių skirstinių dispersijų homogeniškumo patikrinimui naudotas Bartlett'o testas. Pagal normalųji dèsnị pasiskirsčiusių skirstinių, kurių dispersijos buvo lygios, vidurkių palyginimui naudotas Student'o t-testas. Pagal normalųji dèsnị pasiskirsčiusių skirstinių, kurių dispersijos statistiškai reikšmingai skirtųsi, nebuvo. Skirstinių, kurie nebuvo pasiskirstę pagal normalujji dėsni, vidurkiu palyginimui buvo naudojamas Wilcoxon (arba Mann-Whitney U) testas. Nominaliujų kintamujų palyginimui skirtingose grupese buvo naudojamas $\chi^{2}$ kriterijus. Statistiniams skaičiavimams pasirinktas reikšmingumo lygmuo $\alpha=0,05$ ir statistiškai reikšmingai besiskiriančiomis grupėmis buvo laikytos tos, kur $p<=0,05$. Skaitiniams kintamiesiems buvo apskaičiuoti vidurkiai - jie pateikiami tokia forma: vidurkis \pm standartinis nuokrypis.

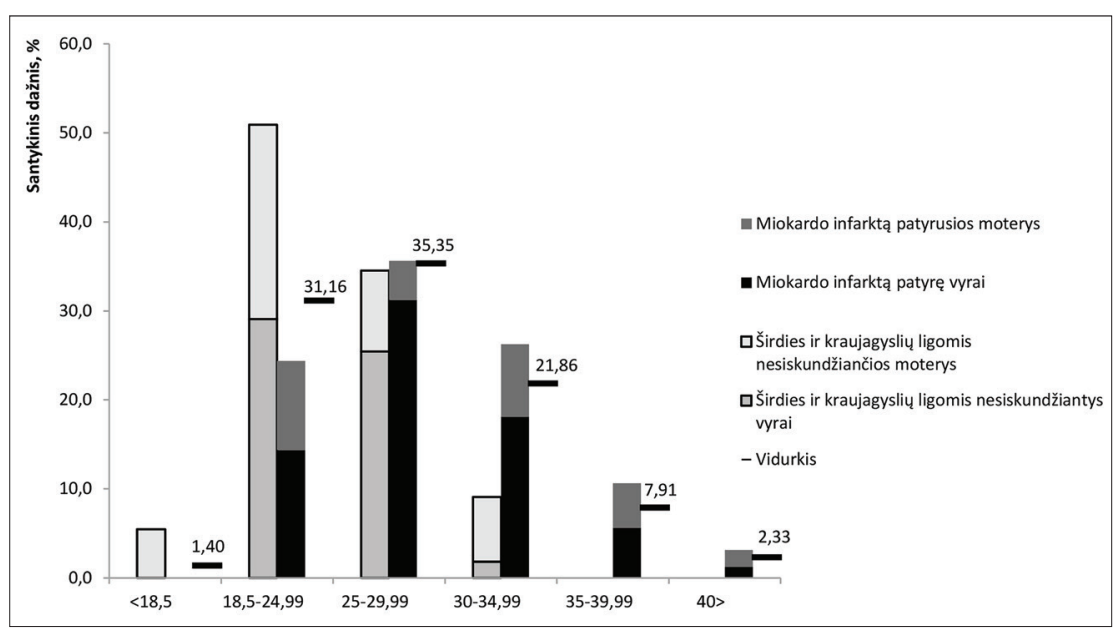

1 pav. Kūno masès indekso kategorijos tarp širdies ir kraujagyslių ligomis nesiskundžiančių bei miokardo infarktą patyrusių pacientų

\section{Tyrimo rezultatai}

Iš viso tyrime dalyvavo 215 tiriamujų: 160 patyrusių miokardo infarktą bei 55 širdies ir kraujagyslių ligomis nesirgę bei šiuo metu šiomis ligomis nesiskundžiantys asmenys. Buvo palygintas šių dviejų grupių vidutinis amžius bei kūno masès indeksas.

Vyrai sudare $67 \%$ tiriamujų, moterys - 33\%. MI patyrę vyrai sudare $78 \%$ visų tyrime dalyvavusių vyrų, MI patyrusios moterys sudare $66 \%$ visų tyrime dalyvavusiu moterų. Skirtumas tarp MI patyrusių vyrų ir MI patyrusių moterų kiekių, atsižvelgiant ị lytinị pasiskirstymą kontrolinèje grupeje, nebuvo statistiškai reikšmingas, nors ir buvo artimas tokiam $(\mathrm{p}=0,052)$.

Visų tyrime dalyvavusių pacientų vidutinis amžius buvo $56,0 \pm 12,6$ metai (svyravo intervale nuo 27 iki 85 metų). Širdies ir kraujagyslių ligomis nesiskundžiančių asmenų grupès amžiaus vidurkis buvo 46,0 $\pm 10,4$ metai (svyravo intervale nuo 27 iki 68 metų), o patyrusių miokardo infarktą - 59,4 $\pm 11,5$ metai (svyravo intervale nuo 29 iki 85 metų). Amžiaus vidurkių skirtumas tarp šių grupių buvo statistiškai reikšmingas $\left(\mathrm{p}=2,26^{*} 10^{-11}\right)$.

Visų tyrime dalyvavusių pacientų vidutinis kūno masès indeksas buvo $28,15 \pm 5,72 \mathrm{~kg} / \mathrm{m}^{2}$ (svyravo intervale nuo 15,62 iki $60,17 \mathrm{~kg} / \mathrm{m}^{2}$ ). Širdies ir kraujagyslių ligomis nesiskundžiančių asmenų grupès kūno masès indekso vidurkis buvo $25,01 \pm 3,72 \mathrm{~kg} / \mathrm{m}^{2}$ (svyravo intervale nuo 15,62 iki $33,08 \mathrm{~kg} / \mathrm{m}^{2}$ ), o patyrusių miokardo infarktą $-29,23 \pm 5,90$ $\mathrm{kg} / \mathrm{m}^{2}$ (svyravo intervale nuo 18,73 iki 60,17 kg/m²). Kūno masès indekso vidurkių skirtumas tarp šių grupių buvo statistiškai reikšmingas $\left(\mathrm{p}=4,41 * 10^{-7}\right)$.

Suskirsčius kūno masès indekso reikšmes pagal kategorijas, nustatyta, kad tik 31\% tiriamųjų buvo normalaus kūno svorio, $1 \%$ tiriamųjų svèrè per mažai ir net $67,45 \%$ tiriamujų buvo per didelio kūno svorio, beveik trečdalis $(32 \%)$ visų tiriamujų buvo nutukę (1 pav.). Patyrę MI pacientai svèrè statistiškai reikšmingai daugiau už tuos, kurie neturèjo nusiskundimų širdies ir kraujagyslių ligomis $\left(\mathrm{p}=9,1 * 10^{-6}\right)$. Net $56 \%$ širdies ir kraujagyslių ligomis nesiskundžiančių asmenų buvo normalaus kūno svorio, $35 \%$ turejo antsvori ir tik $9 \%$ buvo nutukę (I laispnio nutukimas). Tarp patyrusių MI normalaus svorio buvo tik $24 \%$ pacientų, antsvori turejo $36 \%$ pacientų, o nutukę buvo visi likę $40 \%$ MI patyrusių pacientų.

Visų kitu šio tyrimo metu anali- 
1 lentelè. Epikardinio riebalinio audinio storio maksimumų ir tūrių matavimų rezultatai.

\begin{tabular}{|c|c|c|c|c|}
\hline Kintamieji & Visi tiriamieji & $\begin{array}{c}\text { Nesiskundžiantys } \\
\text { širdies ir } \\
\text { kraujagyslių } \\
\text { ligomis }\end{array}$ & $\begin{array}{c}\text { Patyrę } \\
\text { miokardo } \\
\text { infarktą }\end{array}$ & $\underset{\text { reikšmès }}{p}$ \\
\hline SPI, mm & $\begin{array}{l}84,88 \pm 9,98 \\
(64-116)\end{array}$ & $\begin{array}{l}87,82 \pm 10,12 \\
(66-107)\end{array}$ & $\begin{array}{l}83,88 \pm 9,75 \\
(64-116)\end{array}$ & 0,00728 \\
\hline $\mathrm{KPP}_{\text {Mosteller }}, \mathrm{m}^{2}$ & $\begin{array}{l}2,01 \pm 0,25 \\
(1,34-2,92)\end{array}$ & $\begin{array}{l}1,91 \pm 0,23 \\
(1,34-2,30)\end{array}$ & $\begin{array}{l}2,04 \pm 0,25 \\
(1,43-2,92)\end{array}$ & 0,00138 \\
\hline $\mathrm{KPP}_{\text {Du Bois }}, \mathrm{m}^{2}$ & $\begin{array}{l}1,98 \pm 0,23 \\
(1,34-2,71)\end{array}$ & $\begin{array}{l}1,90 \pm 0,22 \\
(1,34-2,28)\end{array}$ & $\begin{array}{l}2,00 \pm 0,23 \\
(1,42-2,71)\end{array}$ & 0,00515 \\
\hline \multicolumn{5}{|l|}{$\begin{array}{l}\text { Epikardinio riebalinio } \\
\text { audinio storio } \\
\text { maksimumai }(\mathrm{mm}) \text { : }\end{array}$} \\
\hline Faktiniai & $\begin{array}{l}8,33 \pm 2,95 \\
(3-21)\end{array}$ & $\begin{array}{l}6,27 \pm 1,33 \\
(3-9)\end{array}$ & $\begin{array}{l}9,04 \pm 3,02 \\
(4-21)\end{array}$ & $1,5^{*} 10^{-12}$ \\
\hline $\begin{array}{l}\text { Normalizuoti pagal } \\
\text { SPI }\end{array}$ & $\begin{array}{l}11,60 \pm 4,56 \\
(3,66-33,14)\end{array}$ & $\begin{array}{l}8,42 \pm 2,18 \\
(3,66-15,82)\end{array}$ & $\begin{array}{l}12,69 \pm 4,66 \\
(4,83-33,14)\end{array}$ & $1,92 * 10^{-13}$ \\
\hline $\begin{array}{l}\text { Normalizuoti pagal } \\
\mathrm{KPP}_{\text {Mosteller }}\end{array}$ & $\begin{array}{l}12,15 \pm 4,07 \\
(4,62-30,21)\end{array}$ & $\begin{array}{l}9,70 \pm 2,40 \\
(4,62-16,79)\end{array}$ & $\begin{array}{l}12,99 \pm 4,19 \\
(6,03-30,21)\end{array}$ & $1,13 * 10^{-9}$ \\
\hline $\begin{array}{l}\text { Normalizuoti pagal } \\
\mathrm{KPP}_{\text {Du Bois }}\end{array}$ & $\begin{array}{l}11,47 \pm 3,87 \\
(4,28-28,71)\end{array}$ & $\begin{array}{l}9,07 \pm 2,23 \\
(4,28-15,41)\end{array}$ & $\begin{array}{l}12,29 \pm 3,98 \\
(5,58-28,71)\end{array}$ & $2,46^{*} 10^{-10}$ \\
\hline \multicolumn{5}{|l|}{$\begin{array}{l}\text { Epikardinio riebalinio } \\
\text { audinio tūriai }\left(\mathrm{cm}^{3}\right) \text { : }\end{array}$} \\
\hline Faktiniai & $\begin{array}{l}141,74 \pm 47,35 \\
(28,58-350,22)\end{array}$ & $\begin{array}{l}101,06 \pm 26,41 \\
(28,58-173,61)\end{array}$ & $\begin{array}{l}155,73 \pm 44,85 \\
(58,27-350,22)\end{array}$ & $<2,2 * 10^{-16}$ \\
\hline $\begin{array}{l}\text { Normalizuoti pagal } \\
\text { SPI }\end{array}$ & $\begin{array}{l}195,78 \pm 68,60 \\
(40,42-438,92)\end{array}$ & $\begin{array}{l}133,83 \pm 34,70 \\
(40,42-275,87)\end{array}$ & $\begin{array}{l}217,08 \pm 64,35 \\
(70,41-438,92)\end{array}$ & $<2,2 * 10^{-16}$ \\
\hline $\begin{array}{l}\text { Normalizuoti pagal } \\
\mathrm{KPP}_{\text {Mosteller }}\end{array}$ & $\begin{array}{l}205,15 \pm 61,38 \\
(52,65-471,00)\end{array}$ & $\begin{array}{l}153,89 \pm 36,47 \\
(52,65-271,74)\end{array}$ & $\begin{array}{l}222,78 \pm 58,28 \\
(87,86-471,00)\end{array}$ & $<2,2 * 10^{-16}$ \\
\hline $\begin{array}{l}\text { Normalizuoti pagal } \\
\mathrm{KPP}_{\text {Du Bois }}\end{array}$ & $\begin{array}{l}193,66 \pm 58,53 \\
(48,73-441,50)\end{array}$ & $\begin{array}{l}143,88 \pm 34,16 \\
(48,73-252,33)\end{array}$ & $\begin{array}{l}210,78 \pm 55,35 \\
(81,22-441,50)\end{array}$ & $<2,2 * 10^{-16}$ \\
\hline
\end{tabular}

Skaitinès reikšmès lentelèje pateikiamos tokia tvarka: vidurkis \pm standartinis nuokrypis (minimali imties reikšmè - maksimali imties reikšmè).

zuotų kintamųjų analizès rezultatai pateikiami 1 lentelèje. Tiek faktiniai matavimai (skilvelių pertvaros ilgiai, epikardinio riebalinio audinio storio maksimumai bei tūriai), tiek ir išvestinių skaičiavimų rezultatai (kūno paviršiaus plotai, sunormalizuoti epikardinio riebalinio audinio storio maksimumai bei tūriai) statistiškai reikšmingai skyrèsi tarp širdies ir kraujagyslių ligomis nesiskundžiančių pacientų bei MI patyrusių pacientų.

\section{Rezultatų aptarimas}

Šiame tyrime dalyvavo 215 pacientų, kuriems buvo atliktas širdies magnetinio rezonanso tomografijos tyrimas ir išmatuoti epikardinio riebalinio audinio tūriai bei storio maksimumai. Tiriamųju imtis buvo padalinta $i \mathfrak{d v i}$ grupes: patyrusius miokardo infarktą $(n=160)$ ir širdies bei kraujagyslių ligomis nesiskundžiančius asmenis $(n=55)$. Abi grupès palygintos tarpusavyje pagal ịvairius rodiklius.

MI patyrusių pacientu grupès tiriamieji buvo vyresni $(p<0,05)$, sergamumo MI kiekių skirtumas tarp skirtingų lyčių, atsižvelgiant ị lytinị pasiskirstymą kontrolinèje grupeje, nebuvo statistiškai reikšmingas $(p=0,052)$. Mahabadi ir kt. bei Shemirani ir kt. atliktuose tyrimuose pateikiami panašūs rezultatai: koronarinius ịvykius išgyvenusių asmenų amžiaus vidurkis buvo didesnis nei tokių ịvykių nepatyrusių tiriamuju, tačiau, prieštaringai nei šiame tyrime, šie tyrejjai nustatè, kad vyrams koronariniai ịvykiai pasitaikydavo dažniau nei moterims $[7,20]$. Kitų autorių tyrimų duomenimis, nei amžius, nei lytis statistiškai reikšmingai nesiskyre tarp MI patyrusių ir širdies bei kraujagylių ligomis nesergančių tiriamujuc $[6,11]$.

Per didelis kūno svoris laikomas vienu iš širdies ir kraujagyslių ligas (tarp jų ir MI) sukeliančiu rizikos veiksniu [4]. İvairių tyrimų, analizavusių epikardinio riebalinio audinio tūrio ar storio įtaką KŠL atsiradimui, kūno masès indekso (KMI) reikšmès tarp persirgusių miokardo infarktu ir koronarinių ịvykių neturejjusių asmenų yra labai kontraversiškos. Šiame tyrime buvo nustatyta, jog MI infarktu persirgusių pacientų kūno masès indekso vidurkis buvo statistiškai reikšmingai didesnis $\left(p=4,41 * 10^{-7}\right)$. Eroglu ir kt. bei Harada ir kt. atliktuose tyrimuose nebuvo nustatyta statistiškai reikšmingų KMI skirtumų tarp kontrolinès sveikujų tiriamujų grupès ir sergančiujų $(p>0,05)[8,11]$. Kunita ir kt. tyrime pateikti visiškai priešingi rezultatai: sergančių širdies ir kraujagyslių ligomis grupès vidutinis KMI buvo statistiškai reikšmingai mažesnis už sveikų asmenų grupès KMI vidurki $\left(22,4 \pm 3,0 \mathrm{~kg} / \mathrm{m}^{2}\right.$ ir $\left.23,8 \pm 3,5 \mathrm{~kg} / \mathrm{m}^{2}, \mathrm{p}=0,013\right)$ [6].

Pasak atliktų tyrimų, padidèjęs epikardinio riebalinio audinio kiekis daro ịtaką širdies kraujagyslių ateroskleroziniam procesui: kuo didesnis apie širdị susikaupusių riebalų tūris, tuo didesnis vainikinių arterijų stenozès ir obstrukcijos laipsnis [9,26-29]. Šiame tyrime nustatyta, kad MI pa- 
2 lentelè. Skirtinguose tyrimuose nustatyti epikardinio riebalinio audinio tūrio vidurkiai.

\begin{tabular}{|c|c|c|c|c|c|c|c|}
\hline \multirow{2}{*}{ Tyrimas } & \multicolumn{3}{|c|}{ Patyrę koronarinius ịvykius } & \multicolumn{3}{|c|}{$\begin{array}{l}\text { Nesiskundžiantys širdies ir } \\
\text { kraujagyslių ligomis }\end{array}$} & \multirow{2}{*}{$\stackrel{p}{p}$} \\
\hline & $\mathrm{n}$ & $\begin{array}{l}\text { ERA tūrio } \\
\text { vidurkis }\left(\mathrm{cm}^{3}\right)\end{array}$ & SN & $\mathrm{n}$ & $\begin{array}{c}\text { ERA tūrio } \\
\text { vidurkis }\left(\mathrm{cm}^{3}\right)\end{array}$ & SN & \\
\hline $\begin{array}{l}\text { Šio darbo } \\
\text { tyrimas }\end{array}$ & 160 & 155,73 & 44,85 & 55 & 101,06 & 26,41 & $<2,2 * 10^{-16}$ \\
\hline $\begin{array}{l}\text { Mahabadi } \\
\text { ir kt. [7] }\end{array}$ & 130 & 121 & - & 3963 & 95 & - & $<0,001$ \\
\hline $\begin{array}{l}\text { Kunita ir } \\
\text { kt. [6] }\end{array}$ & 37 & 126,8 & - & 685 & 105,6 & - & 0,015 \\
\hline $\begin{array}{l}\text { Harada ir } \\
\text { kt. [8] }\end{array}$ & 80 & 117 & 47 & 90 & 95 & 33 & $<0,01$ \\
\hline
\end{tabular}

būtų galima lyginti tarpusavyje ir vertinti rezultatus populiacijos lygmeniu.

Tyrimo ribotumai. Nors duomenys šiam tyrimui rinkti beveik metus, itraukiant daugiau nei $90 \%$ atvykusių pacientų, imtys yra reliatyviai mažos, ypač širdies ir kraujagyslių ligomis nesiskundžiančių asmenų $(\mathrm{n}=55)$. Imtị padidinus, būtų gauti tikslesni rezultatai. Be to, šiame darbe nebuvo atsižvelgta ị kitus širdies ir kraujagyslių ligų rizikos veiksnius, kurie gali daryti įtaką ERA susikaupimui ir koronarinių ivvykių paplitimui. Šio tyrimo metu, ERA tūrius ir storio maksimumus matavo vienas tyrètyrusių asmenų ERA tūriai ir storio maksimumai (faktiniai ir normalizuoti pagal SPI, KPP $\mathrm{Mosteller}_{\text {bei }} \mathrm{KPP}_{\text {Du Bois }}$ ) buvo statistiškai reikšmingai didesni nei širdies ir kraujagyslių ligomis nesiskundžiančių tiriamujų. Lyginant su kitais autoriais, šio tyrimo faktiniai epikardinio riebalyno tūrių vidurkiai abiejose grupèse buvo didesni nei kitų tyrejjų (2 lentelè). Tokia pati tendencija stebima ir lyginant ERA storio reikšmes. Šiame tyrime išmatuotos epikardinio riebalyno storio vidutinès reikšmès (MI grupès - 9,04 $\pm 3,02 \mathrm{~mm}$, širdies ir kraujagyslių ligomis nesiskundžiančių asmenų grupès $-6,27 \pm 1,33 \mathrm{~mm}, \mathrm{p}=1,5^{*} 10^{-12}$ ) buvo didesnès nei kitu tyrejų aprašytuose tyrimuose: Shemirani ir kt. (atitinkamai $5,4 \pm 1,9 \mathrm{~mm}$ ir 4,4 $\pm 1,8 \mathrm{~mm}, \mathrm{p}=0,0001$ ) bei Eroglu ir kt. (atitinkamai $6,9 \pm 1,5 \mathrm{~mm}$ ir $4,4 \pm 0,8 \mathrm{~mm}, \mathrm{p}<0,001)[11,20]$. Šs ERA storių skirtumas veikiausiai stebimas dèl tyrimų metodikų skirtumų: minètų autorių tyrimuose transtorakalinės echokardioskopijos būdu buvo matuojamas vidutinis ERA storis, kiekvienam tiriamajam apskaičiuojant ERA storio vidurkị iš kelių matavimų, o šiame tyrime pasinaudojant MRT keturių kamerų vaizdais buvo fiksuojamos didžiausios ERA storio reikšmès.

Vertinant epikardinị riebalyną, echoskopinio širdies tyrimo metu yra galimybė išmatuoti tik ERA storį, o atliekant širdies kompiuterinę tomografiją ar magnetinio rezonanso tomografiją (MRT) gaunami vaizdai atveria galimybes išmatuoti ne tik epikardinio riebalinio audinio stori, bet ir tūrị $[14,16,30]$. Daugumoje atiktų tyrimų ryšys tarp ERA ir širdies bei kraujagyslių ligų analizuojamas vertinant tik vieną iš šių kintamųų . Visų šio darbo metu nagrinètų tyrimų rezultatai panašūs: lyginant su kontroline širdies ir kraujagyslių ligomis nesiskundžiančių asmenų grupe, epikardinio riebalinio audinio storis ar tūris didesnis koronarinius įvykius patyrusiujų grupejje. Atsižvelgiant į šio tyrimo bei kitų šiame darbe analizuotų tyrimų rezultatus, būtų tikslinga ERA tyrimų metu vertinti ir ERA storį, ir ERA tūrị, o išmatavus juos normalizuoti pasinaudojant populiacijai būdingais SPI ar KPP rodikliais, kad matavimų rezultatus jas - tikètina, kad apskaičiavus kelių nepriklausomų tyrejų žesnè matavimo paklaida.

\section{Išvados}

Patyrusių miokardo infarktą pacientų epikardinio riebalinio audinio tūriai ir storio maksimumai buvo didesni nei širdies ir kraujagyslių ligomis nesiskundžiančių asmenų. Atitinkamai, pirmosios grupès tiriamieji buvo vyresni ir turintys didesnị kūno masès indeksą.

\section{Literatūra}

1. WHO Global atlas on cardiovascular disease prevention and cular_diseases/publications/atlas_cvd/en/

2. World Heart Federation. Vision, Mission \& Values | World Heart Federation. Atnaujinta 2015 [Prieiga per internetą]. http://www. world-heart-federation.org/about-us/vision-mission-values/

3. Mozaffarian D, Benjamin EJ, Go AS, Arnett DK, Blaha MJ, Cushman M. et al. Heart disease and stroke statistics-2015 update: a report from the american heart association. Circulation 2015; 131(4):e29-322.

4. Petrulionienė Ž. Koronarinė širdies liga. Rizikos veiksniai, klinikiniai simptomai ir gydymas. Vilnius: UAB ,Vaistų žinios“, $2010 \mathrm{~m}$.

5. Higienos instituto Sveikatos informacijos centras. 2001-2011 metų rodikliai perskaičiuoti pagal 2011 metų Visuotinio gyventojų surašymo rezultatus. Lietuvos Sveikatos rodiklių sistema (SRS). Atnaujinta 2014 metų spalis [Prieiga per internetą] http://sic.hi.lt/webdps

6. Kunita E, Yamamoto H, Kitagawa T, Ohashi N, Oka T, Utsunomiya $H$. et al. Prognostic value of coronary artery calcium and epicardial adipose tissue assessed by non-contrast cardiac computed tomography. Atherosclerosis 2014; 233(2):447-53.

7. Mahabadi AA, Berg MH, Lehmann N, Kälsch H, Bauer M, Kara K. et al. Association of Epicardial Fat With Cardiovascular Risk Factors and Incident Myocardial Infarction in the General Population: The Heinz Nixdorf Recall Study. Journal of the American College of Cardiology 2013; 61(13):1388-95. atliktų analogiškų matavimų vidurkius, būtų pasiekta macontrol [Prieiga per internetą]. http://www.who.int/cardiovas- 
8. Harada K, Amano T, Uetani T, Tokuda Y, Kitagawa K, Shimbo Y. et al. Cardiac 64-Multislice Computed Tomography Reveals Increased Epicardial Fat Volume in Patients With Acute Coronary Syndrome. The American Journal of Cardiology 2011; 108(8):1119-23.

9. Ulucan S, Kaya Z, Efe D, Keser A, Katlandur H, Aygun F. et al. Epicardial Fat Tissue Predicts Increased Long-Term Major Adverse Cardiac Event in Patients With Moderate Cardiovascular Risk. Angiology 2014.

10. Wu F-Z, Chou K-J, Huang Y-L, Wu M-T. The relation of location-specific epicardial adipose tissue thickness and obstructive coronary artery disease: systemic review and meta-analysis of observational studies. BMC Cardiovascular Disorders 2014; 14(1):62.

11. Eroglu S, Sade LE, Yildirir A, Bal U, Ozbicer S, Ozgul AS. et al. Epicardial adipose tissue thickness by echocardiography is a marker for the presence and severity of coronary artery disease. Nutrition, Metabolism and Cardiovascular Diseases 2009;19(3):211-7.

12. Wang T, Liu Q, Liu C, Sun L, Li D, Liu A. et al. Correlation of Echocardiographic Epicardial Fat Thickness with Severity of Coronary Artery Disease in Patients with Acute Myocardial Infarction. Echocardiography 2014; 31(10):1177-81.

13. Xinzhong CHEN, Zhouyang JIAO, Lei WANG, Zongquan SUN, Xianguo WANG, Dongsheng XIA. et al. Roles of human epicardial adipose tissue in coronary artery atherosclerosis. J Huazhong Univ Sci Technol [Med Sci]. 2010; 30(5):589-93.

14. Talman AH, Psaltis PJ, Cameron JD, Meredith IT, Seneviratne SK, Wong DTL. Epicardial adipose tissue: far more than a fat depot. Cardiovasc Diagn Ther 2014; 4(6):416-29.

15. Rabkin SW. Epicardial fat: properties, function and relationship to obesity. Obesity Reviews 2007; 8(3):253-61.

16. Bertaso AG, Bertol D, Duncan BB, Foppa M. Epicardial Fat: Definition, Measurements and Systematic Review of Main Outcomes. Arq Bras Cardiol 2013; 101(1):e18-28.

17. Corradi D, Maestri R, Callegari S, Pastori P, Goldoni M, Luong TV. et al. The ventricular epicardial fat is related to the myocardial mass in normal, ischemic and hypertrophic hearts. Cardiovasc Pathol 2004; 13(6):313-6.

18. Mazurek T, Zhang L, Zalewski A, Mannion JD, Diehl JT, Arafat H. et al. Human epicardial adipose tissue is a source of inflammatory mediators. Circulation 2003; 108(20):2460-6.

19. Greenstein AS, Khavandi K, Withers SB, Sonoyama K, Clancy O, Jeziorska M. et al. Local inflammation and hypoxia abolish the protective anticontractile properties of perivascular fat in obese patients. Circulation 2009; 119(12):1661-70.

20. Shemirani H, Khoshavi M. Correlation of echocardiographic epicardial fat thickness with severity of coronary artery disease-an observational study. Anadolu Kardiyoloji Dergisi/The Anatolian Journal of Cardiology [Prieiga per internetą $2012 \mathrm{~m}$. vasario $1 \mathrm{~d}$.] http://www.anakarder.com/eng/makale/116/13/ Full-Text

21. Yun KH, Rhee SJ, Yoo NJ, Oh SK, Kim N-H, Jeong J-W. et al. Relationship between the Echocardiographic Epicardial Adipose Tissue Thickness and Serum Adiponectin in Patients with Angina. J Cardiovasc Ultrasound 2009; 17(4):121-6.

22. Mustelier JV, Rego JOC, González AG, Sarmiento JCG, Riverón BV. Echocardiographic parameters of epicardial fat deposition and its relation to coronary artery disease. Arquivos Brasileiros de Cardiologia 2011; 97(2):122-9.

23. Du Bois D, Du Bois EF. Clinical calorimetry: tenth paper a formula to estimate the approximate surface area if height and weight be known. Arch Intern Med (Chic). 1916;XVII(6_2):863871. doi:10.1001/archinte.1916.00080130010002 [Prieiga per internetą]. http://archinte.jamanetwork.com/article. aspx? articleid $=654069$

24. Verbraecken, J., Van de Heyning, P., De Backer, W., \& Van Gaal, L. (2006). Body surface area in normal-weight, overweight, and obese adults. A comparison study. Metabolism, 55(4), 515-524. [Prieiga per internetą]. http://www.metabolismjournal.com/ article/S0026-0495\%2805\%2900437-3/abstract

25. Sardinha LB, Silva AM, Minderico CS, Teixeira PJ. Effect of body surface area calculations on body fat estimates in nonobese and obese subjects. Physiol Meas 2006; 27(11):1197.

26. Ito T, Suzuki Y, Ehara M, Matsuo H, Teramoto T, Terashima M. et al. Impact of epicardial fat volume on coronary artery disease in symptomatic patients with a zero calcium score. Int J Cardiol 2013; 167(6):2852-8.

27. Hajsadeghi F, Nabavi V, Bhandari A, Choi A, Vincent H, Flores F. et al. Increased epicardial adipose tissue is associated with coronary artery disease and major adverse cardiovascular events. Atherosclerosis 2014; 237(2):486-9.

28. Aslanabadi N, Salehi R, Javadrashid A, Tarzamni M, Khodadad B, Enamzadeh E. et al. Epicardial and pericardial fat volume correlate with the severity of coronary artery stenosis. J Cardiovasc Thorac Res 2014; 6(4):235-9.

29. Nakanishi K, Fukuda S, Tanaka A, Otsuka K, Jissho S, Taguchi H. et al. Persistent epicardial adipose tissue accumulation is associated with coronary plaque vulnerability and future acute coronary syndrome in non-obese subjects with coronary artery disease. Atherosclerosis 2014; 237(1):353-60.

30. Dey D, Nakazato R, Li D, Berman DS. Epicardial and thoracic fat - Noninvasive measurement and clinical implications. Cardiovasc Diagn Ther 2012; 2(2):85-93.

\section{DIFFERENCES IN VOLUME AND THICKNESS OF EPICARDIAL ADIPOSE TISSUE BETWEEN PEOPLE WHO HAVE SUFFERED FROM MYOCARDIAL INFARCTION AND THOSE WHO DO NOT COMPLAIN OF CARDIOVASCULAR DISEASES}

D. Austys, E. Bulotaitė, N. R. Valevičienė, R. Stukas

Key words: epicardial adipose tissue, visceral adipose tissue, myocardial infarction.

Summary

Background. Previous studies have revealed that a large accumulation of visceral adipose tissue, including epicardial 
adipose tissue (EAT), increases the risk of cardiovascular disease. However, contradictory results are presented: several studies have demonstrated a significant relationship between coronary artery disease and EAT accumulation, while some studies have failed to observe a significant association. The accumulation of EAT has not previously been studied in Lithuanian population.

Objective. The aim of this study is to compare EAT maximum thicknesses and EAT volumes between people who have suffered from myocardial infarction and those who do not complain of cardiovascular diseases (previously or present).

Object and methods. The study included 25 to 85 years old patients undergoing cardiovascular magnetic resonance imaging (MRI). All patients had potential cardiovascular disease. EAT maximum thicknesses and volumes were measured and calculated using MRI images. Variables such as height, weight, age, gender and disease profiles of patients were obtained_using a questionnaire.

Results. The study involved 215 patients: 160 who have suffered from myocardial infarction and 55 who do not complain of cardiovascular diseases. Men were accounted for $67 \%$ of the sample, women $-33 \%$. Mean age of patients was $56,0 \pm 12,6$ years, mean body mass index $-28,15 \pm 5,72 \mathrm{~kg} / \mathrm{m}^{2}$. Mean maximal thickness of EAT of all patients was $8,33 \pm 2,95 \mathrm{~mm}$, mean EAT volume $-141,74 \pm 47,35 \mathrm{~cm}^{3}$. Mean maximal thicknesses of EAT were $6,27 \pm 1,33 \mathrm{~mm}$ in those who do not complain of cardiovascular diseases and 9,04 $\pm 3,02 \mathrm{~mm}$ in those who have suffered from myocardial infarction $\left(\mathrm{p}=1,5^{*} 10^{-12}\right)$. Respectively, mean EAT volumes were $101,06 \pm 26,41 \mathrm{~cm}^{3}$ and $155,73 \pm 44,85 \mathrm{~cm}^{3}\left(\mathrm{p}<2,2 * 10^{-}\right.$ $\left.{ }^{16}\right)$. EAT volumes and maximal thicknesses were normalized results of all measurements differed significantly.

Conclusion. Patients who have suffered fom myocardial infarction had larger volumes of EAT and larger maximal thicknesses of EAT comparing to those who did not complain of cardiovascular diseases.

Correspondence to: Donatas.Austys@mf.vu.lt

Gauta 2015-03-30 